\title{
ВЕРБАЛІЗАЦІЯ ЕМОЦІЇ СТРАХУ ПАРАЛІНГВІСТИЧНИМИ ФРАЗЕОЛОГІЗМАМИ УКРАЇНСЬКОÏ МОВИ
}

\begin{abstract}
Величко Г. Г. Вербалізація емоції страху паралінгвістичними фразеологізмами української мови.

У статті йдеться про емоцію страху та особливості її вербалізації за допомогою паралінгвістичних фразеологізмів української мови, аналізується від загальних засад функціонування психіки людини, особливо аналізу структури іiї емоційної сфери до поняття мовної ментальності як способу представлення світу та безпосередньо до мовного продукту - паралінгвістичних фразеологізмів. Зроблено спробу з'ясувати, що саме посприяло виникненню деяких стійких висловів та які при цьому спостерігаються семантичні закономірності; ураховується національно-культурна специфіка мовної поведінки.
\end{abstract}

Ключові слова: емоція, страх, паралінгвістичний фразеологізм, фізіологічні зміни, лінгвоемоційна картина світу.

Величко А. Г. Вербализация эмоции страха посредством паралингвистических фразеологизмов украинского языка.

В статье рассматривается эмоция страха, а также особенности ее вербализации посредством паралингвистических фразеологизмов украинского языка, следуя от общих положений функционирования психики человека, особенно анализа структуры его эмоциональной сферы к понятию ментальности языка как способа интерпретации мира и, особенно, к речевому продукту - паралингвистическим фразеологизмам. Произведена попытка выяснить, что могло привести к образованию некоторых стойких выражений, обращается внимание на национально-культурную специфику языкового поведения.

Ключевые слова: эмоция, страх, паралингвистический фразеологизм, физиологические изменения, лингвоэмоциональная картина мира.

Velychko A. G. The verbalization of fear emotion by means of paralinguistic phraseologisms in the Ukrainian language.

The article deals with the fear emotion and the peculiarities of its verbalization by means of paralinguistic phraseologisms in the Ukrainian language based on general principles of psyche functioning, especially of emotional sphere structure analysis, to the conception of language mentality as a mode of interpretation of the world, and paralinguistic phraseologisms as their speech product. The author investigates the creation of certain set expressions taking into account national cultural peculiarities of linguistic behaviour.

Key words: emotion, fear, paralinguistic phraseologism, physiological changes, linguoemotional picture of the world.

Емоції людини постають як частина нашого психічного «Я», запорука повноцінності життя, ознака здоров'я. Ч. Дарвін приписував їм біологічну природу, маючи на увазі тваринне походження людських емоцій. Так, емоція страху як первинна (базова) співвідносилася з певним адаптивним комплексом, а саме: захист - спершу як відповідь на біль чи загрозу болю (наприклад, для горя таким комплксом є депривація - утрата об’єкта, що приносить задоволення) [1, с. 16].

О.Г. Г. Величко, 2010. 
Не можна однозначно сказати, що сам характер емоцій людини змінився у процесі філогенезу, бо, на думку Є. Ільїна, «зміна способу задоволення потреби не свідчить про зміну характеру емоцій, які при цьому відчуває людина, $\langle\ldots>$ у людини $є$ вольовий механізм пригнічення експресії емоцій» [1, с. 18]. Інакше кажучи, будь-яка сильна емоція викликає в людини певний фізіологічний стан, супроводжується активністю специфічних ділянок головного мозку, аналогічно до переживання таких емоцій i тваринами, однак людину, на відміну від тварини, будуть стримувати суспільні норми та стандарти поведінки, чи суперего за З. Фрейдом, що i складають вольовий механізм пригнічення експресії емоцій.

П. Анохін визначив емоцію як «фізіологічний стан організму, що має яскраво виражене суб'єктивне забарвлення та охоплює всі види відчувань та переживань людини - від травмуючих страждань до високих форм радості та соціального життєвідчуття» [1, с. 339]. Емоції постають не тільки як засіб оцінки майбутньої ситуації, але і як механізм завчасної та адекватної підготовки до неї за рахунок мобілізації психічної та фізичної енергії. Не зайвим буде схарактеризувати цей механізм, акцентуючи увагу на фізіологічному компонентові емоційної реакції. 3'ясувати особливості переживання страху конкретною людиною видається можливим завдяки ретельному спостереженню за іiі психічним та фізичним станом, зокрема й мовленням. Кожна емоція є, певним чином, відображенням соціальної взаємодії індивідів. Тому можемо говорити про їхню етнічну складову, коли ментальні зв'язки накладаються на суб'єктивне відображення емоціогенної ситуації і ми маємо цілком закономірно утворений мовний продукт. Так, фразеологічні одиниці розглядаються як відображення емоційного досвіду носія мови, «як результат первинної колективної рефлексії внутрішніх переживань» [4, с. 26].

А. Попкова вказує на необхідність вживання терміна «лінгвоемоційна картина світу» «для позначення особливим чином вербалізованого емоційного простору особистості, що інтегрує ії психоемоційну та мовну складові» [4, с. 26]. Можемо зазначити, що мовний знак, реперзентуючи реалію, своєю внутрішньою формою фіксує певну інтерпретацію цієї реалії, а сукупність таких інтерпретацій являє собою систему знань, яка входить до мовної картини світу. П. Селігей, розглядаючи питання про внутрішню форму слова, робить висновок про те, що «семантика, власне, $\mathrm{i}$ $\epsilon$ не що інше, як потужний пласт етномовно опосередкованих образівуявлень людини про дійсність, тобто більш узагальнено: мова $є$ системою розуміння або світорозумінням» $[5$, с. 25$]$.

Наше дослідження передбачає з'ясування семантичних та структурних особливостей паралінгвістичних фразеологічних одиниць, утворення та закріплення яких у мові послужило джерелом для характеристики емоції страху. Іншими словами, завдяки засобам паралінгвістичної фразеології, дати відповідь на запитання: як українець 
уявляє, переживає страх та, головне, говорить про нього, описує своє сприйняття?

Страх - це емоційний стан, що відображає захисну біологічну реакцію людини або тварини при переживанні ними реальної чи уявної небезпеки задля збереження їх здоров’я та благополуччя. Отже, для людини як біологічної істоти виникнення страху не тільки доцільне, але й корисне. Проте для людини як соціальної істоти страх часто стає перешкодою в досягненні поставленої мети. Мовна репрезентація емоцій страху метонімічно виникає від назв «емоціогенних» предметів [5, с. 26], явищ, життєвих ситуацій, подій, що не залишають людину байдужою, неодмінно викликають у неї ті чи ті переживання. Частина назв емоцій постає як метонімія від назв реальних явищ, здебільшого пов'язаних 3 емоційним переживанням, інші - як метафора відповідно до міфічних образів та донаукових уявлень, якими раніше людина намагалася пояснити свої емоції. Що ж стосується фразеологізмів, досліджуваних у статті, то їх семантика пов'язана передусім із паралінгвістичним компонентом, який розуміється як допоміжний засіб комунікації поряд із вербальними.

Звернімося безпосередньо до мовного матеріалу, що складає лінгвоемоційну картину світу. Ми визначили такі фразеологізми, у семантиці яких засвідчено наявність емоційного компонента. Отже, емоція страху репрезентується таким синонімічним рядом ФО: волос в 'яне (зав'яв) [6, с. 123]; [аж] волосся піднімається (підіймається, встає, лізе) / піднялося (стало, полізло) вгору (догори) [6, с. 124]; волос (волосся) дибом (дубом, дуба) стає /став (стало) [6, с. 123]; вбирати (втягувати) / ввібрати (втягти, втягнути) голову в плечі [6, с. 54]; брови полізли на лоба [6, с. 46]; лиця нема / не було [6, с. 430]; спадати /спасти з лиця [6, с. 678]; [аж] мінитися / перемінитися на лиці (в лиці, на обличчі і т. ін) [6, с. 391]; очі мало (як) не вискочать (не вискакують) з голови (з орбіт, з лоба $i$ m. ін.) [6, с. 477]; [аж (i)] очі на лоб (на лоба рідше догори і т. ін.) лізуть / полізли [6, с. 473]; роботи / зробити великі очі [6, с. 601].

Так, скажімо, вирази волос в'яне (зав'яв) та волос (волосся) дибом (дубом, дуба) стає /став (стало) за сумою значень своїх компонентів можна тлумачити як антоніми, де протилежність значення надають дієслова зав'яв - став (дві протилежні за фізичною наповненістю дії). Річ у тім, що здавалося б протилежні на перший погляд речі можуть бути показником одного і того ж явища, страх може викликати різні реакції: від збудження до гальмування. До того ж сам страх має варіації від легких форм боязкості та боязкості до паніки і жаху. Тому чи не логічно заявити, що волосся піднімається вгору, коли комусь дуже страшно, а в'яне, коли людині моторошно, безпосередньої миттєвої загрози їі життю немає, однак тоді це більше схоже на побоювання, яке $\epsilon$ це людською формою переживання небезпеки і виникає на підставі аналізу ситуації, зіставлення та узагальнення сприйманих явищ, прогнозування вірогідності небезпеки 
або ступеня ризику. Це інтелектуальна емоція, «розумний страх», пов'язаний із передбаченням небезпеки.

Вислови лиия нема / не було - «хто-небудь змінився на виду від раптового хвилювання, хвороби і т. ін. (почуття страху - Г. В.)»; спадати /спасти з лиия - «ставати блідим, змученим; худнути; марніти» (від ситуативного страху чи його передбачення); [аж] мінитися / перемінитися на лиці (на обличчі $i \mathrm{~m}$. ін) можуть бути використані при характеристиці зовнішнього прояву страху. Ці фразеологічні одиниці називають не лише фізіологічний бік емоційної реакції, вони описують певні процеси зміни міміки людини, зовнішності загалом.

Фразеологізми, які передають інформацію про вираз очей, $\epsilon$ передусім мімічними: очі мало (як) не вискочать (не вискакують) з голови (з орбіт, з лоба i m. ін.); [аж (i)] очі на лоб (на лоба рідше догори i m. ін.) лізуть / полізли; роботи / зробити великі очі. Ілюстраціями показано, як саме зовнішній прояв страху був проаналізований людиною та збережений у мові. Ч. Дарвін писав, що при страхові очі розкриті ширше, ніж у стані спокою, нижня повіка напружена, а верхня - ледь піднята. Брови майже прямі та видаються дещо припіднятими. Внутрішні кути брів зсунуті один до одного, на лобі з'являються горизонтальні зморшки. За таких умов ми можемо схарактеризувати міміку з двох позицій: на основі іiі фізіологічних параметрів (тонус, сила, комбінація м'язових скорочень, симетрія асиметрія, динаміка, амплітуда), а також у термінах тих психічних явищ, яким відповідають певні мімічні знаки. Мімічні ФО ввібрали в себе досвід про людський організм, зокрема про фізіологічні процеси в зоровому аналізаторі. Під час впливу прямих сонячних променів на очі, людина їх прикриває, коли ж в око потрапляє пил та інші чужорідні тіла, вона починає кліпати. Крім цього, $є$ ще ряд процесів, які виникають при різних емоційних станах, мають свою специфіку вираження очима та поглядом на рівні відповідних реакцій. Наприклад, фразеологізм робити / зробити великі очі означає «виявляти подив, здивування (і страху - Г. В.)». Для страху, що виникає при збудженні базолатерального ядра мигдалини, $\epsilon$ характерним переважання викиду адреналіну над норадреналіном. Зростає, хоч і не набагато, кількість кортизола в крові, що свідчить про збільшення активності кори надниркових. Такі вегетативні зміни пояснюють те, що під час психологічних станів на кшталт подиву, здивування, страху очі людини мають здатність розширюватися. Це насамперед стосується зіниць, які при мінімальному освітленні змінюють розмір, аби пропустити якомога більше світла. Тому не дивно, що досвід людини про такі особливості зору став підгрунтям для оформлення фразеологізму.

Як показують експериментальні дослідження, міміка виконує основне навантаження при вираженні різних емоційних станів, зокрема і страху, що знайшло відображення у вербальних еталонах експресії. Водночас мімічна картина страху часто інтерпретується як здивування. Наприклад: [аж] 
мінитися / перемінитися на лиці (в лищі, на обличчі і вискочать (не вискакують) з голови (з орбіт, з лоба і т. ін.); [аж (i)] очі на лоб (на лоба рідше догори і т. ін.) лізуть / полізли.

Такі стійкі вислови, як-от: кров ударила в лище (в обличчя, до лиия) [6, с. 315]; цокотіти (цокотати, цокати) зубами [6, с. 758]; дзвонити зубами [6, с. 196]; кидати / кинути в дрож (в трясию) [6, с. 291]; серце як (ледве, мало, трохи i т. ін.) не вискочить [з грудей] [6, с. 642]; дрож пробирає (проймає, пробиває) / пробрав (пройняв, пробив і т. ін) [6, с. 220]; [аж] мороз дере (подирає, пробиває $і$ m. ін.) / подер (подрав, пробрав $і$ m. iн.) по спині (по шкірі, за плечі і т. ін.) [6, с. 406]; кров холоне (крижаніє, застигає) / захолола (застигла) у жилах [6, с. 315] не є власне паралінгвістичними. Фразеологізми кров холоне (крижаніє, застигає) / захолола (застигла) у жилах мають відтінки у значенні і передають до того ж психологічний стан тривоги, яка $\epsilon$ передумовою страху. Може виникнути питання щодо доцільності опису деяких 3 них, адже вони відображають фізіологічні зміни в організмі в момент дії стимула (який викликає страх). До того ж, як зазначає Г. Колшанський, «рівень безпосереднього вираження емоційного стану людини не є комунікативним рівнем узагалі, а лише біологічною якістю людини як одного із видів живих істот $<. .>$. Ця сфера психічної діяльності людини не є сферою комунікації i цілком підпорядкована психофізіології <..>. До паралінгвістичних засобів варто долучити лише ті функціонально виправдані прояви фізичного стану суб'єкта, що говорить, які необхідні для доповнення пробілів вербальної комунікації» [2, с. 32]. Отже, проблема полягає в тому, як бути 3 тими мовними одиницями, що не мають у своєму значенні власне паралінгвістичного компонента. Вони ніби залишаються на периферії дослідження.

Е. Маслико, визначаючи психолінгвістичну природу паралінгвістичних явищ, виокремив проміжні паралінгвістичні засоби (ті, що характеризують емоційний стан) [2, с. 32-33].

Зауважимо також, що позиція Г. Колшанського стосується передусім невербальних засобів спілкування, наша ж наукова розвідка пов'язується не 3 власне невербальними компонентами комунікації (що, однак, $\epsilon$ важливою складовою дослідження), а 3 тим, як специфічні, національні жести, рухи, міміка закріпилися в мові через вербалізацію у фразеологічні одиниці. Так, Джеймс пише: «Я зовсім не можу уявити, якою може залишитися емоція страху, якщо виокремити 3 неї відчуття, пов'язані 3 посиленням серцебиття, коротким диханням, тремтінням губ, розслабленням м'язів, «гусячою шкірою» та збудженням у череві» [1, с. 42]. Звичайно, ці закономірності в діяльності нервової системи є біологічною спадщиною, що склалася протягом складного шляху еволюції живих організмів. Це своєрідний поштовх для дослідження, адже, маючи «однакові» вихідні параметри розвитку нервової системи та психіки зокрема, кожна людина 
як індивід та кожна етнічна спільнота як сукупність цих індивідів вирізняється своїми особливостями відображення об'єктивної реальності. Як зазначає О. Селігей, давня і середньовічна людина не могла правильно кваліфікувати причини душевного та фізіологічного дискомфорту, а тому метафорично пояснювала ці процеси у психіці й організмі через асоціації 3 уже відомими їй явищами природи і за допомогою бінарних опозицій або певних донаукових уявлень [5, с. 29]. Вони досить яскраво та оригінально втілені й у мові, наприклад: кров холоне (крижаніє, застигає) / захолола (застигла) у жилах - «кому-небудь дуже страшно, моторошно, тривожно i т. ін.». Тож можна припустити, що в момент переживання страху на фізіологічному рівні дійсно відбувається зниження рухової діяльності, проявляється пасивно-оборонна реакція, яку I. Павлов пов’язував 3 «гальмуванням кіркових центрів». Суб'єктивні відчуття вказують на те, що кров перестає розширюватися зі звичайною швидкістю судинами організму, завмирає, застигає (як зменшення інтенсивності руху), захолола та крижаніє (як втрата теплової енергії), однак не замерзає (що може бути незворотнім процесом), бо, як відомо, цей стан характеризують як «уявну смерть». К. Ушинский дав яскравий психологічний опис сильного страху: «Дія страху саме тому і жахлива, що він, зупиняючи діяльність душі, у той же час звертає іï увагу до предмету страху. У ці хвилини, згідно з влучним висловом народної мудрості, ми «ні живі ні мертві»: ми не живемо тому, що діяльність нашої душі зупинена, а діяльність є життям нашої душі; ми ще не померли тому, що відчуваємо в усій силі цю жахливо болісну зупинку життя» [1, с. 169]. Фраземи на кшталт кидати / кинути в дрож (в трясцю) - «викликати в кого-небудь стан нервового збудження, надмірного хвилювання, страху і т. ін.»; дрож пробирає (проймає, пробиває) / пробрав (пройняв, пробив $i$ m. ін) - «хтонебудь тремтить від холоду, страху, хвилювання, нервового напруження» передають узаємозв'язок фізичного відчуття холоду та психологічного стану страху, які викликають однакові фізіологічні зміни організму. Тремтіння людини під час небезпеки має на меті змусити людський організм повернутися до нормального психічного стану. Тремтіння провокує приток крові до тіла та іï інтенсивне поширення судинами організму (особливо важливо при загальному переохолодженні), при перелякові тремтіння характеризує готовність м'язів до втечі або нападу. В. Аперсян та Ю. Апресин уводять поняття «тілесної метафори душі», яка дозволяє інтерпретувати емоції завдяки схожості симптоматики певних фізіологічних та емоційних станів. Учені формулюють тлумачення страху, уподібненого до холоду. Вираз [аж] мороз дере (подирає, пробиває $і$ m. ін.) / подер (подрав, пробрав $i$ m. ін.) по спині (по шкірі, за плечі $i \mathrm{~m}$. ін.) має два значення, причому перше $є$ прямим, поверховим - «хтось відчуває озноб, здригається, тремтить від холоду, хвилювання, упливу чого-небудь на органи чуття і т. ін.», друге - визначає знаковість, символічність дії / стану, є глибинним. 
Цікавими, на наш погляд, є такі фраземи: клубок підкочується (niдступас) / підкотився (підступив) до горла [6, с. 301]; [аж] кров кинулася до обличчя (в обличчя, у лище) [6, с. 314]; давати / дати волю ногам [6, с. 177]; брати / взяти ноги на плечі (в руки, за пояс) [6, с. 42]. Їх тлумачення не вказує на переживання страху, щонайменще - вони фіксують хвилювання, однак це знову ж таки «стислий опис» психофізіологічної реакції або характеристика інстинкту самозбереження на кшталт «бігти що є сили від небезпеки, від причини страху». Ці вислови не вказують на причини сильної емоційної реакції чи особливості іiі протікання, вони ніби називають ті процеси, що відбуваються в організмі після спаду загального напруження: клубок підкочується (niдcmynaє) / підкотився (підступив) до горла - «кому-небудь спазми стискають горло від сильного хвилювання, переживання і т. ін.», тобто важкість дихання, що може бути причиною пережитого «бойового збудження» (термін психолога Б. Теплова). У психології немає однозначного погляду на функціонування та виникнення емоцій (так званих елементарних емоцій) у зв'язку з органічними процесами (концепції Джеймса-Ланге, КеннонаБарта). Згідно 3 цими теоріями можна говорити, що першопричинами виникнення емоційних станів $\epsilon$ зміни фізіологічного характеру, які відбуваються в організмі. Виникаючи під впливом зовнішніх або внутрішніх стимулів, вони згодом відображаються в голові людини через систему зворотних нервових зв'язків та породжують відчуття певного емоційного тону. Анатомо-фізіологічною основою цих емоцій є лімбічні структури ЦНС, а також процеси, що протікають у таламусі та гіпоталамусі [3, с. 67]. Спробуємо проаналізувати процес, який охарактеризовано фразеологізмом, згідно 3 теорією Кеннона-Барта, що виникла як альтернатива до теорії Джеймса-Ланге. Перший етап сприйняття впливу емоціогенного стимулу (зорові, слухові стимули, що викликають стан хвилювання, занепокоєння тощо). Другий етап переробка центральними структурами головного мозку імпульсів, які поступають від рецепторів, 3 одночасною передачею збудження в кору головного мозку та до інших тілесних органів (це своєрідне «перекодування» сприйнятої інформації на «мову мозку»). Останній етап має двоякий характер: по-перше, це виникнення емоційного стану, який переживається суб'єктивно (індивідуальний рівень переживань, сила дії стимулу, що виражається в особистісному сприйнятті фрустраційної ситуації); по-друге, це поява нервово-м'язової реакції організму (безпосередньо спазми в горлі, відчуття в ньому своєрідного клубка, який заважає дихати і вільно говорити). Отже, клубок біля горла є відповіддю м'язів на вплив певного емоціогенного чинника.

Фізіологічним поясненням таких змін $є$ надто сильне збудження, при якому звужується голосова щілина задля того, аби через неї проходило менше повітря, а через це й менше подразнювалися рецептори голосових 
зв'язок. Так організм через саморегуляцію намагається послабити цілеспрямований потік імпульсів до центральної нервової системи. Інший стійкий вираз брати / взяти ноги на плечі (в руки, за пояс) означає «1) тікати, бігти, іти геть; 2) прискорювати ходу, поспішати» - бажання врятувати своє життя, уберегти свою фізичну цілісність вимагає втечі від причини страху. Особливо стенічний страх може сприяти мобілізації резервів людини за рахунок викиду в кров додаткової кількості адреналіну, наприклад, при активно-оборонній його формі (утечі від небезпеки).

Оцінюючи результати дослідження семантичної мотивації паралінгвістичних фразеологізмів, у яких закарбовано переживання емоції страху, можемо підсумувати, що більшість сталих виразів досить чітко відображає зовнішні особливості емоційного реагування (переважно мімічні), передають внутрішній стан людини (через фізіологічні зміни організму). Вони постають у структурі мови як перші спроби первісної людини пояснити свій емоційний стан засобами рідної мови, тим самим відображають особливості світовідчуття українця.

\section{Література}

1. Ильин Е. П. Эмоции и чувства / Евгений Павлович Ильин. - [2-е изд.]. - СПб., 2007. $-783 \mathrm{c}$.

2. Колшанский Г. В. Паралингвистика / Геннадий Владимирович Колшанский. [2-е изд.]. - М. : КомКнига, 2005. - 96 с.

3. Немов Р. С. Психология : [учеб. для студ. высш. учеб. заведений] : в 3-х кн. / Роберт Семенович Немов. - [4-е изд]. - М. : Гуманит. изд. центр ВЛАДОС, 2003. - Кн. 1 : Общие основы психологии. -688 с.

4. Попкова А. Н. Языковая репрезентация эмоционального концепта CTPAX / Анастасия Николаевна Попкова // Семантика и прагматика слова и текста : [международный сборник научных статей] / отв. ред., сост. Л. А. Савёлова. Архангельськ : Поморский университет, 2005. - 216 с.

5. Селігей П. О. Внутрішня форма назв емоцій в українській мові / П. О. Селігей // Мовознавство. - 2001. - № 1. - С. 24-32.

6. Словник фразеологізмів української мови / [уклад. В. М. Білоноженко та ін.]. К. : Наукова думка, 2008. - 1104 с.

7. Ужченко В. Д. Фразеологія сучасної української мови : [навчальний посібник] / В. Ужченко, Д. Ужченко. - К. : Знання, 2007. - 494 с. 